DOI: https://doi.org/10.47405/mjssh.v6i12.1178

\begin{tabular}{|c|c|}
\hline & Malaysian Journal of Social Sciences and Humanities (MJSSH) \\
\hline Malaysian Journal of & Volume 6, Issue 12, December 2021 \\
\hline 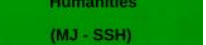 & e-ISSN : 2504-8562 \\
\hline & $\begin{array}{l}\text { Journal home page: } \\
\text { www.msocialsciences.com }\end{array}$ \\
\hline
\end{tabular}

\title{
Pengetahuan Konseptual dan Prosedural dalam Matematik: Satu Sorotan Literatur Sistematik
}

\author{
Siti Aishah binti Yuswan', Siti Mistima Maat1 \\ ${ }^{1}$ Fakulti Pendidikan, Universiti Kebangsaan Malaysia (UKM), Bangi, Selangor, Malaysia \\ Correspondence: Siti Aishah binti Yuswan (itiaishahyuswan@gmail.com)
}

\begin{abstract}
Abstrak
Pengetahuan konseptual dan prosedural merupakan dua jenis pengetahuan yang harus dimiliki oleh pelajar untuk menguasai matematik. Kedua-dua pengetahuan ini mempunyai kepentingan tersendiri dan memberikan pengaruh terhadap tahap penguasaan pelajar dalam matematik. Sorotan literatur bersistematik dijalankan bagi menganalisis kajian lepas berhubung kaitan pengetahuan konseptual dan prosedural dengan tahap pencapaian matematik pelajar. Kajian ini juga dijalankan untuk meninjau pendekatan dan kaedah yang digunakan untuk meningkatkan pengetahuan konseptual dan prosedural pelajar. Sebanyak 30 kajian dalam tempoh lima tahun terkini telah terpilih dalam kajian sistematik ini dan kajian-kajian tersebut diperoleh melalui pangkalan data Scopus, Web of Science dan ERIC. Dapatan kajian menunjukkan terdapat banyak pendekatan dan kaedah yang digunakan untuk meningkatkan pengetahuan konseptual pelajar. Peningkatan dalam pengetahuan konseptual ini meningkatkan tahap penguasaan matematik pelajar. Dapatan kajian ini boleh dimanfaatkan oleh semua pihak terutamanya guru-guru dan institusi pendidikan bagi meningkatkan tahap penguasaan pelajar dalam matematik. Kajian ini juga boleh dijadikan sebagai panduan dalam penghasilan model atau kaedah pembelajaran yang bertujuan untuk meningkatkan pengetahuan konseptual dan prosedural pelajar dalam usaha untuk membantu meningkatkan pencapaian pelajar dalam matematik.
\end{abstract}

Kata kunci: pengetahuan konseptual, pengetahuan prosedural, penguasaan, matematik

\section{Conceptual and Procedural Knowledge in Mathematics: A Systematic Literature Review}

\begin{abstract}
Conceptual and procedural knowledge are knowledge that must be acquired by students to perform in mathematics. Both knowledge have their own characteristics and each will affect students' achievement in mathematics. This systematic review analyzed previous studies on the relation of conceptual and procedural knowledge with students' achievement in mathematics. This study is also done to explore the used of learning approaches and methods in order to improve students' conceptual and procedural knowledge. 30 articles have been selected from three databases which are Scopus, Web of Science and ERIC. Findings show that there are many approaches and methods used to increase students' conceptual knowledge. This increasing leads to the increasing of students' performance in mathematics. The result of this study is beneficial for teachers and education institution for improving students' performance in mathematics. This study can also be a guideline in constructing learning model and method for the purpose of increasing students' conceptual and procedural knowledge as for helping them improving their achievement in mathematics.
\end{abstract}


Keywords: conceptual knowledge, procedural knowledge, performance, mathematics

\section{Pengenalan}

Tahap penguasaan pelajar dalam matematik masih lagi berada pada tahap yang kurang memuaskan. Ini adalah berdasarkan keputusan PISA (Programme International Student Assessment) dan TIMSS (Trends in International Mathematics and Science Study) yang menunjukkan bahawa penguasaan pelajar di Malaysia masih berada pada tahap sederhana. Keputusan PISA 2018 bagi literasi matematik menunjukkan penurunan skor iaitu 440 skor berbanding 446 skor pada tahun 2015 (Bernama 2019). Bagi keputusan TIMSS 2015, Malaysia berada di tangga ke-22 daripada 39 buah negara dengan mata sebanyak 465 bagi subjek Matematik (GPS Bestari 2016).

Matematik merupakan mata pelajaran yang mencabar dan memerlukan pemahaman konsep yang kuat. Matematik juga banyak melibatkan pengetahuan berbentuk abstrak di mana pelajar perlu mempunyai tahap kemampuan yang agak tinggi untuk menguasainya. Aras dan tahap kesukaran yang agak tinggi dalam matematik menyebabkan wujudnya persepsi dan tanggapan bahawa matematik sebagai mata pelajaran yang sukar difahami. Keupayaan pelajar dalam penguasaan matematik adalah berkait rapat dengan kemampuan mereka untuk memahami konsep matematik itu sendiri. Namun begitu, kebanyakan pelajar mengalami kesukaran untuk memahami konsep matematik dengan baik (Rahman \& Ahmar, 2016).

Pengetahuan konseptual dan prosedural merupakan dua jenis pengetahuan yang sangat diperlukan oleh pelajar dalam penguasaan matematik. Kedua-dua pengetahuan ini adalah penting dan diperlukan dalam membuat penyelesaian masalah matematik (Yurniwati, 2019). Kajian berkaitan kepentingan kedua-dua pengetahuan ini telah dibincangkan sejak sekian lama dan telah menemui pelbagai hasil dapatan. Terdapat dua teori berkaitan urutan pengetahuan yang diperoleh pelajar. Teori pertama menyatakan bahawa pelajar membina pengetahuan konseptual terlebih dahulu dan dengan itu mengaplikasikan pengetahuan untuk menentukan strategi dan prosedur untuk menyelesaikan masalah (Vamvakoussi et al., 2019). Teori kedua pula, Vamvakoussi et al. (2019) menjelaskan bahawa pelajar membina dan memperoleh pengetahuan melalui pengulangan aktiviti yang melibatkan penyelesaian masalah.

\section{Sorotan Literatur}

Pengetahuan konseptual dan prosedural merupakan dua jenis pengetahuan yang diperlukan untuk pelajar-pelajar menguasai kemahiran matematik. Pengetahuan konseptual merupakan pengetahuan yang melibatkan kebolehan dalam membuat penaakulan berkaitan sesuatu konsep atau kemahiran (RittleJohnson \& Schneider, 2015). Pengetahuan prosedural pula melibatkan kemampuan pelajar untuk menunjukkan jalan kira atau langkah demi langkah pengiraan dalam penyelesaian masalah (RittleJohnson \& Schneider, 2015). Secara umumnya, pengajaran konseptual memfokuskan kepada prinsip domain pengetahuan manakala pengajaran prosedural memberi fokus terhadap urutan langkah dalam penyelesaian masalah (Rittle-Johnson et al., 2016).

Pengetahuan konseptual dan prosedural dapat meningkatkan kemahiran asas pelajar dalam matematik. Kedua-dua pengetahuan ini adalah penting kerana ianya akan diaplikasikan untuk berhadapan dengan situasi yang baru dan kompleks (Sylviyani, 2017). Penguasaan dalam kedua-dua pengetahuan ini dapat memberikan impak yang besar terhadap penguasaan dan pencapaian matematik pelajar (Rittle-Johnson et al., 2016). Hubungan antara kedua-dua pengetahuan ini adalah jelas di mana penguasaan dalam satu pengetahuan ini akan membawa kepada penguasaan terhadap satu lagi pengetahuan tersebut (RittleJohnson et al., 2015).

Kepentingan kedua-dua pengetahuan prosedural dan konseptual dalam pendidikan amat dititikberatkan untuk memastikan pelajar mampu menguasai matematik dengan baik. Pengetahuan prosedural yang 
baik menyebabkan pelajar berupaya untuk menyelesaikan masalah matematik melalui penggunaan pelbagai simbol dan notasi matematik. Namun demikian, pelajar tidak berupaya untuk memahami dan menaakul tentang proses penyelesaian masalah tersebut sekiranya tidak disertakan dengan pengetahuan konseptual (Wawan et al., 2019).

Terdapat persoalan berhubung bagaimana dan apa perkaitan antara kedua-dua pengetahuan konseptual dan prosedural. Terdapat pendapat umum yang bersetuju bahawa pengetahuan konseptual menyokong dan membawa kepada pengetahuan prosedural (Rittle-Johnson et al., 2015). Namun, terdapat juga pendapat yang menyatakan sebaliknya. Pertikaian tentang hubungan antara pengetahuan konseptual dan prosedural ini telah lama berlangsung dan ia adalah berdasarkan perbezaan pendapat berkaitan perkembangan dan pengajaran dalam pengetahuan konseptual dan prosedural (Rittle-Johnson et al., 2015).

Tinjauan sistematik yang dijalankan ini adalah bagi menjawab persoalan seperti berikut: (1) Sejauh mana hubungan antara pengetahuan konseptual dan prosedural dengan keupayaan penguasaan matematik pelajar? dan (2) Apakah cara yang boleh digunakan untuk meningkatkan pengetahuan konseptual dan prosedural?

\section{Metod Kajian}

Kajian sistematik dijalankan bagi mengenalpasti dan menjawab persoalan kajian berkaitan bidang yang dikaji serta halatuju kajian pada masa akan datang (Torres-Carrion et al., 2018). Fokus kajian ini adalah berkaitan pengetahuan konseptual dan prosedural dalam pembelajaran matematik. Artikel-artikel dicari secara elektronik dengan menggunakan tiga pangkalan data iaitu Scopus, Web of Science dan ERIC. Pencarian artikel ini menggunakan kata kunci "conceptual and procedural knowledge" AND "mathematics". Beberapa kriteria dalam pencarian artikel-artikel telah ditetapkan seperti berikut; (1) tahun penerbitan artikel dari 2017 sehingga 2021, (2) jenis dokumen iaitu artikel dan (3) Bahasa Inggeris sebagai bahasa pilihan. Pemilihan Bahasa Inggeris sebagai salah satu kriteria dalam pencarian artikel adalah kerana skop dan bidang kajian yang lebih banyak dan terbuka dapat diperoleh melalui kriteria ini.

Pencarian artikel dilakukan melalui empat fasa. Fasa pertama adalah pencarian dengan menggunakan kata kunci di mana sebanyak 92 artikel diperoleh melalui pangkalan data Scopus, 76 artikel melalui pangkalan data Web of Science dan 99 artikel melalui pangkalan data ERIC. Jumlah artikel yang diperoleh dalam fasa pertama ini adalah sebanyak 267 artikel. Seterusnya dalam fasa kedua, limitasi mengikut kriteria dalam pemilihan dan pencarian artikel telah dilakukan. Melalui proses saringan ini, sebanyak 21 artikel daripada pangkalan data Scopus, 21 artikel daripada Web of Science dan 22 artikel daripada ERIC telah diperoleh menjadikan jumlah artikel sebanyak 64 buah artikel. Daripada 64 buah artikel ini, hanya 48 buah artikel yang berjaya dimuat turun iaitu 15 artikel daripada Scopus, 15 artikel daripada Web of Science and 18 artikel daripada ERIC. Seterusnya, proses saringan dijalankan di mana terdapat artikel yang sama diperoleh daripada ketiga-tiga pangkalan data. Melalui proses ini, terdapat 18 buah artikel yang sama diperoleh dan menjadikan jumlah artikel yang baru adalah sebanyak 18 buah. Rajah 1 di bawah menunjukkan ringkasan proses pemerolehan artikel dilakukan. 
DOI: https://doi.org/10.47405/mjssh.v6i12.1178

Rajah 1: Carta Alir proses pemerolehan artikel menggunakan aplikasi PRISMA

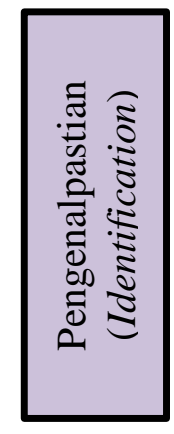

Rekod carian menggunakan
kata kunci:
Scopus $=92$, WoS $=76$,
ERIC $=99$
$(\mathrm{n}=267)$
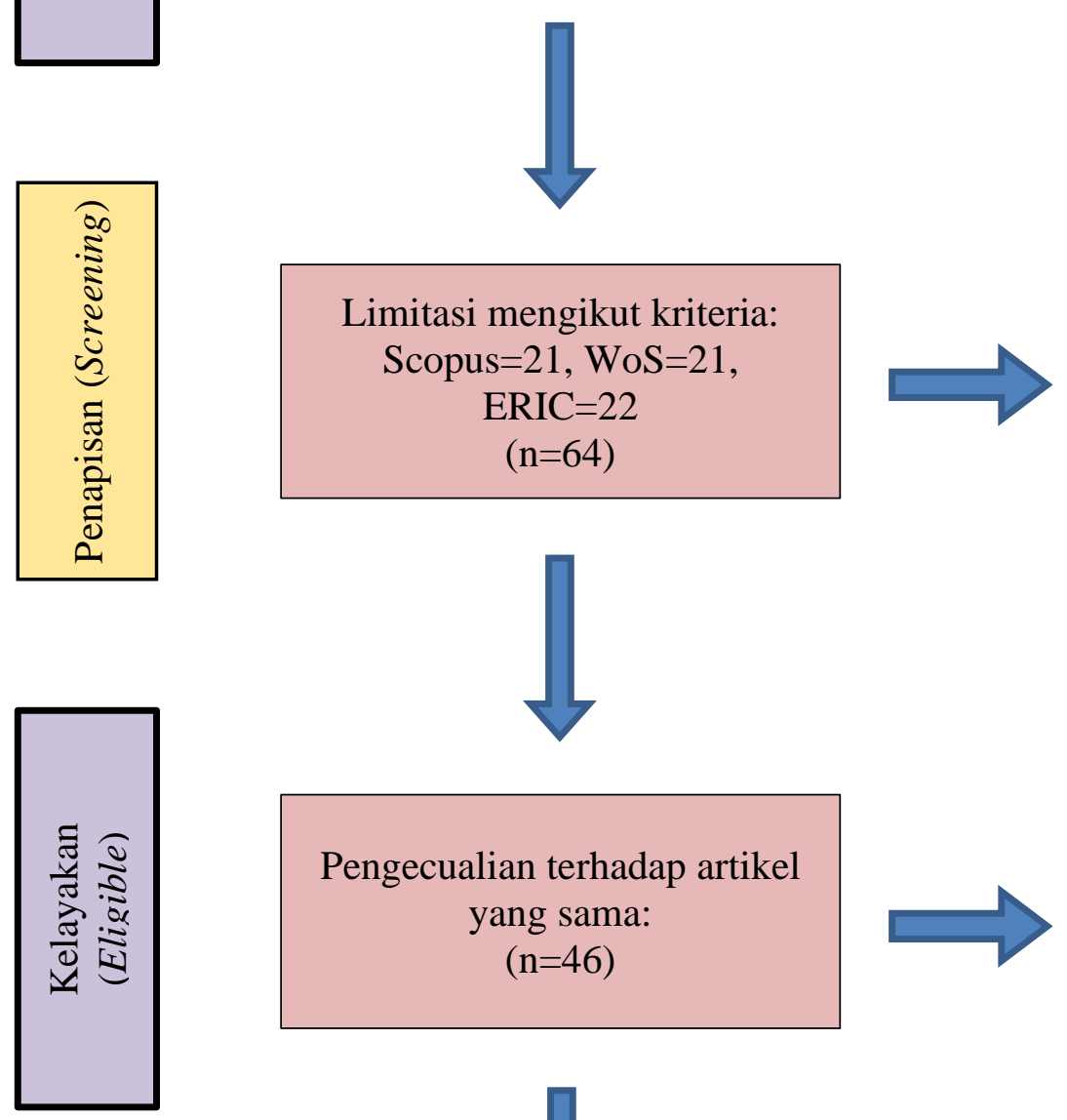

Penetapan kriteria:

- Tahun penerbitan (2017 - 2021)

- Jenis dokumen (artikel)

- Bahasa (Bahasa Inggeris)

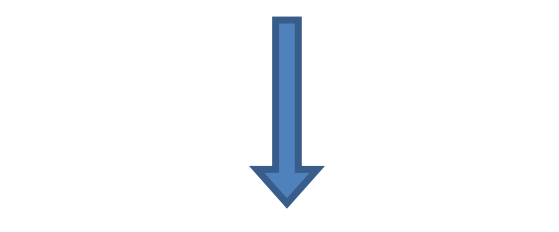

Pengecualian terhadap artikel yang sama: $(n=46)$

18 artikel yang sama dikenal pasti dalam ketiga-tiga pangkalan data

Artikel yang diakses dan dimuat turun:

$$
(n=30)
$$




\section{Dapatan Kajian}

Jadual di bawah menjelaskan dapatan kajian daripada penelitian terhadap artikel-artikel yang dipilih.

\begin{tabular}{|c|c|c|c|c|}
\hline Bil & Penulis & $\begin{array}{c}\text { Bilangan } \\
\text { peserta kajian }\end{array}$ & $\begin{array}{l}\text { Kaedah/Model yang } \\
\text { digunakan }\end{array}$ & Dapatan kajian \\
\hline 1 & $\begin{array}{l}\text { Chua Ye Ling, } \\
\text { Sharifah Osman, } \\
\text { Mohd Fadzil Daud, } \\
\text { Wan Nazdah Wan Hussin } \\
\text { (2019) }\end{array}$ & $\mathrm{n}=48$ & Aplikasi Vee Diagram & $\begin{array}{l}\text { Pengetahuan konseptual dan pengetahuan prosedural } \\
\text { meningkatkan pencapaian dan penguasaan pelajar dalam } \\
\text { matematik (Ling et al., 2019) }\end{array}$ \\
\hline 2 & $\begin{array}{l}\text { Friederike Blume, } \\
\text { Thomas Dresler, } \\
\text { Caterina Gawrilow, } \\
\text { Ann-Christine Ehlis, } \\
\text { Richard Goellner, } \\
\text { Korbinian Moeller } \\
(2021)\end{array}$ & $\mathrm{n}=81$ & Within-task approach & $\begin{array}{l}\text { Pengetahuan konseptual dan pengetahuan prosedural adalah faktor } \\
\text { dan penentu kepada pencapaian dan penguasaan pelajar dalam } \\
\text { matematik (Blume et al., 2021). }\end{array}$ \\
\hline 3 & $\begin{array}{l}\text { Jessica M. Namkung, } \\
\text { Nicole Bricko } \\
(2020)\end{array}$ & $\mathrm{n}=48$ & $\begin{array}{l}\text { Intervensi penyelesaian } \\
\text { persamaan algebra }\end{array}$ & $\begin{array}{l}\text { Pengetahuan konseptual membantu meningkatkan pencapaian dan } \\
\text { penguasaan pelajar dalam matematik (Namkung \& Bricko, 2020). }\end{array}$ \\
\hline 4 & $\begin{array}{l}\text { Mekonnen Legessea, } \\
\text { Kakoma Lunetab, } \\
\text { Tadele Ejigu } \\
(2020)\end{array}$ & $\mathrm{n}=101$ & Discourse-based instruction & $\begin{array}{l}\text { Pengetahuan konseptual membantu meningkatkan pencapaian dan } \\
\text { penguasaan pelajar dalam matematik (Legesse et al., 2020). }\end{array}$ \\
\hline 5 & $\begin{array}{l}\text { Rajiv Satsangi, } \\
\text { Rachel Hammer, } \\
\text { Emily C. Bouck } \\
\text { (2019) }\end{array}$ & $\mathrm{n}=3$ & Video modelling & $\begin{array}{l}\text { Pembelajaran dengan menggunakan video modelling membantu } \\
\text { meningkatkan pengetahuan konseptual pelajar dan seterusnya } \\
\text { meningkatkan penguasaan pelajar dalam matematik (Satsangi et } \\
\text { al., 2020). }\end{array}$ \\
\hline
\end{tabular}




\begin{tabular}{|c|c|c|c|c|}
\hline 6 & $\begin{array}{l}\text { Nicolas Morales, } \\
\text { Pablo Dartnell } \\
\text { David Maximiliano Gómez } \\
\text { (2020) }\end{array}$ & $\mathrm{n}=57$ & Strategi kongruen & $\begin{array}{l}\text { Strategi kongruen adalah tidak memadai untuk } \\
\text { menjelaskan berkaitan tahap penguasaan matematik } \\
\text { pelajar (Morales et al., 2020). }\end{array}$ \\
\hline 7 & $\begin{array}{l}\text { Utkun Aydın } \\
\text { Meric Ozgeldi } \\
(2017)\end{array}$ & $\mathrm{n}=58$ & Ujian matematik & $\begin{array}{l}\text { Pengetahuan konstekstual, konseptual dan prosedural } \\
\text { adalah penting dalam penyelesaian masalah } \\
\text { matematik (Aydın \& Özgeldi, 2019) }\end{array}$ \\
\hline 8 & $\begin{array}{l}\text { Stephanie Herppich, } \\
\text { Jorg Wittwer } \\
\text { (2018) }\end{array}$ & $\mathrm{n}=42$ & Pendekatan Novel & $\begin{array}{l}\text { Pengetahuan konseptual dan pengetahuan prosedural } \\
\text { adalah berbeza namun mempunyai hubungan dan } \\
\text { perkaitan yang sangat hampir (Herppich \& Wittwer, } \\
\text { 2018) }\end{array}$ \\
\hline 9 & $\begin{array}{l}\text { Silvana Maria R. } \\
\text { Joao Lopes } \\
\text { Celia Oliveira } \\
\text { Sharon Judge } \\
\text { (2018) }\end{array}$ & $\mathrm{n}=697$ & Ujian penilaian bertulis & $\begin{array}{l}\text { Pengetahuan prosedural diperlukan pada peringkat } \\
\text { awal intervensi untuk mengelakkan berlakunya } \\
\text { kesilapan dalam penyelesaian masalah matematik } \\
\text { (Watson et al., 2018). }\end{array}$ \\
\hline 10 & $\begin{array}{l}\text { Johann Engelbrecht, } \\
\text { Christer Bergsten, } \\
\text { Owe Kagesten } \\
\text { (2017) }\end{array}$ & $\mathrm{n}=25$ & Temubual & $\begin{array}{l}\text { Pengetahuan konseptual dan pengetahuan prosedural } \\
\text { adalah penting dan dilihat daripada tiga aspek; } \\
\text { 1) Menghubungkait kedua-dua aspek konseptual } \\
\text { dan prosedural. } \\
\text { 2) Pembinaan kefahaman konseptual melalui } \\
\text { aspek prosedural. } \\
\text { 3) Memudahkan penyelesaian masalah } \\
\text { berbentuk konseptual dengan menggunakan } \\
\text { pengetahuan prosedural (Engelbrecht et al., } \\
\text { 2017) }\end{array}$ \\
\hline
\end{tabular}




\begin{tabular}{|c|c|c|c|c|}
\hline 11 & $\begin{array}{l}\text { Bethany Rittle-Johnson } \\
\text { (2017) }\end{array}$ & $\mathrm{n}=180$ & Eksperimen rawak & $\begin{array}{l}\text { Penguasaan matematik memerlukan kefahaman } \\
\text { terhadap pengetahuan konseptual dan prosedural. } \\
\text { Perkembangan kedua-dua pengetahuan ini bersifat } \\
\text { dua hala (Rittle-Johnson, 2017) }\end{array}$ \\
\hline 12 & $\begin{array}{l}\text { Keri L. Stoyle, } \\
\text { Bradley J. Morris } \\
\text { (2017) }\end{array}$ & $\mathrm{n}=134$ & $\begin{array}{l}\text { Pembelajaran bersemuka dan } \\
\text { aplikasi teknologi (blogging) }\end{array}$ & $\begin{array}{l}\text { Pembelajaran dengan aplikasi teknologi (blogging) } \\
\text { membantu meningkatkan pengetahuan konseptual } \\
\text { pelajar (Stoyle \& Morris, 2017) }\end{array}$ \\
\hline 13 & $\begin{array}{l}\text { Hutkemri Zulnaidi, } \\
\text { Sharifah Norul Akmar Syed Zamri } \\
\text { (2017) }\end{array}$ & $\mathrm{n}=345$ & Perisian GeoGebra & $\begin{array}{l}\text { Pembelajaran dengan menggunakan perisian } \\
\text { GeoGebra membantu meningkatkan pengetahuan } \\
\text { konseptual pelajar (Zulnaidi \& Zamri, 2017). }\end{array}$ \\
\hline 14 & $\begin{array}{l}\text { Christer Bergsten, } \\
\text { Johann Engelbrecht, } \\
\text { Owe Kagesten } \\
\text { (2017) }\end{array}$ & $\mathrm{n}=949$ & Ujian penilaian & $\begin{array}{l}\text { - Hubungan antara keyakinan dan prestasi pelajar } \\
\text { junior bagi pengetahuan konseptual adalah lebih } \\
\text { rendah berbanding pengetahuan prosedural. } \\
\text { - Hubungan antara keyakinan dan prestasi pelajar } \\
\text { senior bagi pengetahuan konseptual adalah lebih } \\
\text { tinggi berbanding pengetahuan prosedural } \\
\text { (Bergsten et al., 2017). }\end{array}$ \\
\hline 15 & $\begin{array}{l}\text { Derek Hurrell } \\
\text { (2021) }\end{array}$ & Artikel sorotan literatur & & $\begin{array}{l}\text { - Proses pembelajaran perlu mengambilkira kedua- } \\
\text { dua pengetahuan konseptual dan procedural. } \\
\text { - Pada kebanyakan masa, pengetahuan konseptual } \\
\text { mendahului pengetahuan prosedural (Hurrell, } \\
\text { 2021). }\end{array}$ \\
\hline
\end{tabular}




\begin{tabular}{|c|c|c|c|c|}
\hline 16 & $\begin{array}{l}\text { Mariana Levin } \\
(2018)\end{array}$ & $\mathrm{n}=1$ & Sistem strategi & $\begin{array}{l}\text { Pengetahuan konseptual dan prosedural merupakan sistem } \\
\text { maklumat yang kompleks dan mempunyai hubungkait } \\
\text { antara satu sama lain (Levin, 2018). }\end{array}$ \\
\hline 17 & $\begin{array}{l}\text { Saiman, } \\
\text { Puji Wahyuningsih, } \\
\text { Hamdani } \\
(2017)\end{array}$ & $n=25$ & Temubual & $\begin{array}{l}\text { Pengetahuan konseptual adalah lebih penting berbanding } \\
\text { pengetahuan prosedural dalam matematik (Saiman et al., } \\
\text { 2017). }\end{array}$ \\
\hline 18 & $\begin{array}{l}\text { Yurniwati } \\
(2018)\end{array}$ & $\mathrm{n}=4$ & Pendekatan multisensory & $\begin{array}{l}\text { Pendekatan multisensory membantu untuk mempelajari } \\
\text { konsep abstrak. Kefahaman terhadap konsep matematik } \\
\text { harus bermula dengan pengetahuan konseptual dan diikuti } \\
\text { dengan pengetahuan prosedural (Yurniwati, 2019) }\end{array}$ \\
\hline 19 & $\begin{array}{l}\text { Xenia Vamvakoussi, } \\
\text { Maria Bempeni, } \\
\text { Stavroula Poulopoulou, } \\
\text { Ioanna Tsiplaki } \\
(2019)\end{array}$ & $\mathrm{n}=80$ & Soal selidik & $\begin{array}{l}\text { Perkembangan pengetahuan konseptual dan prosedural } \\
\text { bergantung kepada perbezaan individu (Vamvakoussi et al., } \\
\text { 2019) }\end{array}$ \\
\hline 20 & $\begin{array}{l}\text { Mehmet Fatih Ocal } \\
\text { (2017) }\end{array}$ & $\mathrm{n}=55$ & Perisian Geogebra & $\begin{array}{l}\text { Pembelajaran dengan menggunakan perisian GeoGebra } \\
\text { membantu meningkatkan pengetahuan konseptual pelajar, } \\
\text { namun tidak mempengaruhi skor pelajar dalam pengetahuan } \\
\text { prosedural (Ocal, 2017). }\end{array}$ \\
\hline 21 & $\begin{array}{l}\text { Katja Lenz, } \\
\text { Anika Dreher, } \\
\text { Lars Holzapfel, } \\
\text { Gerald Wittmann } \\
\text { (2019) }\end{array}$ & $\mathrm{n}=235$ & Instrumen ujian & $\begin{array}{l}\text { Pengetahuan konseptual dan prosedural membantu } \\
\text { meningkatkan pencapaian dan penguasaan pelajar dalam } \\
\text { matematik (Lenz et al., 2020). }\end{array}$ \\
\hline
\end{tabular}




\begin{tabular}{|c|c|c|c|c|}
\hline 22 & $\begin{array}{l}\text { Utkun Aydın } \\
\text { (2018) }\end{array}$ & $\mathrm{n}=758$ & Angle Test (AT) & $\begin{array}{l}\text { Pelajar perempuan menunjukkan tahap penguasaan terhadap } \\
\text { pengetahuan prosedural yang lebih tinggi berbanding pelajar } \\
\text { lelaki (Aydin, 2018) }\end{array}$ \\
\hline 23 & $\begin{array}{l}\text { Otun Ismaila Wasiu, } \\
\text { Olaoye Adetunji Abiola } \\
\text { (2019) }\end{array}$ & $\mathrm{n}=182$ & Strategi solve-reflect-post & $\begin{array}{l}\text { Strategi solve-reflect-post membantu meningkatkan } \\
\text { pengetahuan konseptual dan prosedural pelajar dalam } \\
\text { matematik algebra (Otun \& Olaoye, 2019). }\end{array}$ \\
\hline 24 & $\begin{array}{l}\text { Mun Yee Lai, } \\
\text { Virginia Kinnear, } \\
\text { Chun Ip Fung } \\
\text { (2019) }\end{array}$ & $\mathrm{n}=2$ & Kaeah Field-test & $\begin{array}{l}\text { Kaedah Field-test meningkatkan keyakinan pelajar dan } \\
\text { membantu meningkatkan pengetahuan konseptual pelajar } \\
\text { dalam matematik (Lai et al., 2019). }\end{array}$ \\
\hline 25 & $\begin{array}{l}\text { Farzad Radmehr, } \\
\text { Michael Drake } \\
(2020)\end{array}$ & $\mathrm{n}=8$ & Temubual & $\begin{array}{l}\text { Terdapat perbezaan tahap pengetahuan metakognitif pelajar } \\
\text { mengikut tahap perkembangan pelajar (Radmehr \& Drake, } \\
\text { 2020). }\end{array}$ \\
\hline 26 & $\begin{array}{l}\text { Khisna Yumniyati, } \\
\text { Imam Sujadi, } \\
\text { Diari Indriati } \\
\text { (2019) }\end{array}$ & $\mathrm{n}=2$ & $\begin{array}{c}\text { Temubual berasaskan } \\
\text { tugasan }\end{array}$ & $\begin{array}{l}\text { Pelajar menunjukkan tahap pengetahuan konseptual dan } \\
\text { prosedural yang baik pada tahap kognisi (cognition level) } \\
\text { (Yummiyati et al., 2019) }\end{array}$ \\
\hline 27 & $\begin{array}{l}\text { Masooma Ali Al-Mutawa } \\
\text { Ruby Thomas, } \\
\text { Abdulla Eid, } \\
\text { Enaz Yousef Mahmoud, } \\
\text { Moosa Jaafar Fateel } \\
\text { (2019) }\end{array}$ & $\mathrm{n}=350$ & Ujian matematik & $\begin{array}{l}\text { Lebih ramai pelajar menguasai pengetahuan prosedural } \\
\text { berbanding pengetahuan konseptual (Al-Mutawah et al., } \\
\text { 2019) }\end{array}$ \\
\hline
\end{tabular}




\begin{tabular}{llll}
\hline 28 & $\begin{array}{l}\text { Jackson Pasini Mairing } \\
(2017)\end{array}$ & $\mathrm{n}=2$ & $\begin{array}{l}\text { Pelajar yang lemah dalam penguasaan matematik } \\
\text { mempunyai masalah dalam memahami pernyataan } \\
\text { masalah disebabkan kefahaman konseptual dan } \\
\text { prosedural yang rendah (Mairing, 2016). }\end{array}$ \\
\hline $29 \begin{array}{l}\text { Emily N. Daubert, } \\
\text { Geetha B. Ramani } \\
(2019)\end{array}$ & $\mathrm{n}=74$ & $\begin{array}{l}\text { Pelajar yang menguasai dwi-bahasa menunjukkan } \\
\text { penguasaan dalam kefahaman matematik yang } \\
\text { lebih baik berbanding pelajar yang hanya } \\
\text { menguasai satu bahasa (Daubert \& Ramani, 2019). }\end{array}$ \\
\hline $\begin{array}{l}\text { Yu-Ping Chang, } \\
\text { Janina Krawitz, } \\
\text { Stanislaw Schukajlow, } \\
\text { Kai-Lin Yang } \\
(2019)\end{array}$ & $\mathrm{n}=292$ & $\begin{array}{l}\text { Sesi penilaian } \\
\text { Pelajar Taiwan mempunyai tahap pengetahuan } \\
\text { konseptual dan prosedural yang lebih tinggi } \\
\text { berbanding pelajar Jerman (Chang et al., 2020). }\end{array}$ & \begin{tabular}{l} 
Model tugasan \\
\hline
\end{tabular} \\
\hline
\end{tabular}




\section{Perbincangan Kajian}

Berdasarkan hasil dapatan kajian, kedua-dua pengetahuan konseptual dan prosedural mempengaruhi tahap keupayaan pelajar dalam penguasaan matematik. Hasil penelitian juga mendapati pengetahuan konseptual lebih dilihat memberi kesan terhadap peningkatan penguasaan pelajar dalam matematik berbanding pengetahuan prosedural. Penguasaan dalam pengetahuan konseptual akan secara langsung mempengaruhi penguasaan pelajar dalam pengetahuan prosedural (Ling et al., 2019). Menurut Ling et al. (2019) juga, apabila pelajar mempunyai kefahaman yang mendalam berkaitan prinsip dan konsep sesuatu topik pembelajaran, pelajar akan berupaya untuk menyelesaikan masalah yang diberikan dengan baik dan tepat. Pelajar yang mempunyai pengetahuan konseptual yang tinggi berupaya untuk memahami hubungan antara konsep dan prosedur serta mampu membuat penaakulan dan memberi penjelasan tentang sesuatu fakta dengan baik (Yurniwati, 2019).

Intervensi yang digunakan dalam proses pengajaran dan pembelajaran turut mempengaruhi tahap penguasaan pengetahuan konseptual dan prosedural pelajar. Menerusi analisis terhadap artikel-artikel yang diperoleh, pelbagai kaedah dan model digunakan sebagai pemboleh ubah bagi melihat pengaruh keberkesanannya terhadap peningkatan pengetahuan konseptual dan prosedural pelajar. Terdapat 12 kajian yang dijalankan dengan menggunakan pelbagai pendekatan dan model yang bertujuan untuk membantu meningkatkan tahap penguasaan matematik pelajar melalui pemahaman konseptual dan prosedural. Hasil dapatan kajian menunjukkan pendekatan dan kaedah yang digunapakai ini terbukti berkesan dalam meningkatkan pemahaman konseptual dan prosedural pelajar dan seterusnya meningkatkan penguasaan matematik pelajar.

Pengajaran yang eksplisit dengan penggunaan bahan manipulatif konkrit dapat membina kefahaman konseptual yang tinggi dan seterusnya meningkatkan penguasaan pelajar dalam matematik (Namkung \& Bricko, 2020). Ini disokong dengan kenyataan bahawa bahan manipulatif konkrit sebagai bahan yang umum digunakan dalam pembelajaran matematik peringkat rendah kerana ia berupaya untuk mengekspresikan dan sebagai perwakilan visual terhadap konsep abstrak (Beilstein, 2019). Aktiviti dengan menggunakan bahan konkrit ini dapat meningkatkan kualiti pembelajaran di mana ia menarik minat pelajar untuk mengikuti proses pembelajaran. Interaksi pelajar dengan persekitaran dan bahan konkrit membantu pelajar untuk membina pengetahuan dengan lebih baik. Aspek kinestatik yang terlibat dalam proses pembelajaran melalui aktiviti hands-on yang dijalankan dengan bantuan bahan visual turut dapat meningkatkan kefahaman konseptual pelajar (Yurniwati, 2019).

Penglibatan pelajar secara langsung dalam proses proses pengajaran dan pembelajaran juga merupakan salah satu kaedah yang boleh digunakan untuk meningkatkan penguasaan pelajar dalam matematik. Pendekatan ini boleh diaplikasikan melalui pembelajaran dalam berkumpulan di mana melalui pendekatan ini, pelajar akan dapat berinteraksi dan berkomunikasi sesama mereka berkaitan sesuatu topik pembelajaran. Kajian berkenaan pendekatan ini yang dirujuk sebagai pengajaran berasaskan perbincangan (discourse-based instruction) agak kurang dijalankan, namun berdasarkan kajian yang dijalankan oleh Legesse et al. (2020), menunjukkan bahawa pengetahuan konseptual membantu meningkatkan pencapaian dan penguasaan pelajar dalam matematik. Pendekatan ini dilihat dapat membantu pelajar untuk membuat perkaitan dan hubungan antara konsep dan prosedur bagi membina kefahaman matematik dengan lebih baik (Legesse et al., 2020). Walau bagaimanapun, menurut Legesse et al. (2020), keberkesanan pendekatan ini bergantung kepada sejauh mana penglibatan pelajar dalam aktiviti perbincangan yang dijalankan serta keupayaan mereka dalam membuat penerangan, justifikasi, membuat kesimpulan, menyoal dan membandingbezakan prosedur penyelesaian masalah.

Kepesatan perkembangan arus teknologi telah memberi kesan dan perubahan terhadap proses pengajaran dan pembelajaran di seluruh dunia. Aplikasi teknologi dalam pendidikan telah mengubah pengajaran dan pembelajaran berbentuk tradisional kepada pengajaran dan pembelajaran yang berbentuk interaktif. Teknologi seperti perisian pendidikan, papan putih interaktif dan komputer diintegrasikan dalam kelas untuk menyediakan peluang pembelajaran yang lebih komprehensif kepada pelajar. Hasil dapatan kajian berdasarkan tiga artikel yang melibatkan integrasi teknologi dalam pengajaran menunjukkan bahawa pendekatan dengan aplikasi teknologi membantu meningkatkan pengetahuan konseptual pelajar (Ocal, 2017; Stoyle \& Morris, 2017; Zulnaidi \& Zamri, 2017). 
Pembelajaran dengan aplikasi teknologi membantu pelajar untuk melihat konsep matematik dan seterusnya dapat mengaitkan konsep yang difahami dengan kehidupan seharian mereka (Zulnaidi \& Zamri, 2017). Aplikasi teknologi seperti perisian Geogebra digunakan dalam pengajaran dan pembelajaran adalah bertujuan untuk menjadikan pembelajaran lebih bermakna dan berkonsepsi (Ocal, 2017). Walau bagaimanapun, menerusi penelitian berdasarkan artikel yang diperoleh tidak mendapati sebarang kesan terhadap peningkatan pengetahuan prosedural melalui integrasi teknologi dalam pengajaran dan pembelajaran matematik.

Persoalan berkaitan hubungan antara pengetahuan konseptual dan prosedural telah lama dibincangkan oleh para cendekiawan matematik. Terdapat pelbagai pandangan berbeza tentang peranan dan pengaruh pengetahuan konseptual dan prosedural terhadap penguasaan matematik pelajar. Pandangan umum menyatakan bahawa hubungan antara pengetahuan konseptual dan prosedural adalah berbentuk dua hala dan saling berulang (Kadijevich, 2018). Kadijevich (2018) turut menjelaskan bahawa penguasaan dalam pengetahuan konseptual akan meningkatkan penguasaan dalam pengetahuan prosedural dan juga sebaliknya.

Pelajar harus menguasai kedua-dua pengetahuan konseptual dan prosedural kerana setiap satunya diperlukan bagi menyelesaikan pelbagai bentuk masalah matematik. Tugasan yang berbentuk prosedural memerlukan pengetahuan prosedural melalui langkah-langkah penyelesaian yang betul manakala tugasan berbentuk konseptual pula memerlukan pemahaman yang jelas berhubung konsep, prinsip dan hubungan antara konsep (Kadijevich, 2018). Walau bagaimananpun, Kadijevich (2018) menyatakan bahawa adalah mustahil bagi pelajar untuk menyelesaikan tugasan berbentuk konseptual tanpa adanya pengetahuan prosedural dan ia juga berlaku sebaliknya. Walaupun terdapat kajian yang menyatakan bahawa pengetahuan prosedural memberi kesan yang kurang efektif terhadap penguasaan pelajar dalam matematik, namun keseimbangan antara pengetahuan konseptual dan prosedural adalah perlu bagi memastikan ilmu yang disampaikan lebih difahami dan bermakna (Ocal, 2017).

\section{Implikasi Kajian}

Berdasarkan kajian sistematik yang dijalankan, dapatan kajian dapat dimanfaatkan oleh guru-guru matematik khususnya serta institusi pendidikan bagi meningkatkan tahap penguasaan pelajar melalui pengukuhan pengetahuan konseptual dan prosedural. Selain itu, kajian sistematik yang dijalankan menunjukkan terdapat pelbagai model dan pendekatan yang boleh diaplikasikan bagi tujuan meningkatkan kefahaman konseptual dan prosedural pelajar. Melihat kepada kepentingan kedua-dua pengetahuan konseptual dan prosedural terhadap penguasaan matematik, kajian ini boleh dijadikan panduan dalam pembinaan model dan strategi pengajaran dan pembelajaran di dalam kelas. Pemilihan model dan strategi pengajaran yang bersesuaian adalah amat penting kerana ia mempengaruhi keberkesanan pembelajaran.

\section{Kesimpulan}

Kedua-dua pengetahuan konseptual dan prosedural adalah penting bagi pelajar kerana kedua-duanya sangat diperlukan untuk menguasai kemahiran menyelesaikan masalah matematik (Yurniwati, 2019). Guru seharusnya jelas bahawa pengetahuan tidak hanya disampaikan daripada seseorang kepada seseorang yang lain semata-mata, namun ianya dibina oleh pelajar itu sendiri melalui proses interaksi dengan persekitaran pembelajaran. Persekitaran merupakan contoh nyata yang dapat digunakan oleh pelajar untuk membuat perkaitan antara idea-idea matematik dengan pengalaman kehidupan seharian mereka (Zulnaidi \& Zamri, 2017). Menurut Zulnaidi dan Zamri (2017) juga, persekitaran pelajar juga dapat membantu pelajar membina konsep pembelajaran yang baharu dan ini seterusnya akan meningkatkan lagi kefahaman konseptual pelajar sekaligus menambahbaik pengetahuan prosedural mereka.

Guru harus membantu pelajar untuk membina pengetahuan konseptual melalui pelbagai model pembelajaran dengan bantuan media pembelajaran yang bersesuaian. Penguasaan dalam pengetahuan 
konseptual dan prosedural dalam kalangan guru juga harus ditingkatkan (Yurniwati, 2019). Hal ini kerana guru perlu mempunyai kefahaman konseptual yang tinggi agar guru-guru dapat menyampaikan ilmu dengan lebih baik dan berkesan. Ini akan membawa kepada perubahan yang positif terhadap hasil pembelajaran dalam matematik.

\section{Rujukan}

Al-Mutawah, M. A., Thomas, R., Eid, A., Mahmoud, E. Y., \& Fateel, M. J. (2019). Conceptual understanding, procedural knowledge and problem-solving skills in mathematics: High school graduates work analysis and standpoints. International Journal of Education and Practice, 7(3), 258-273. https://doi.org/10.18488/journal.61.2019.73.258.273

Aydin, U. (2018). Conceptual and Procedural Angle Knowledge: Do Gender and Grade Level Make a Difference? International Journal for Mathematics Teaching and Learning, 19(1), 22-46.

Aydın, U., \& Özgeldi, M. (2019). The PISA Tasks: Unveiling Prospective Elementary Mathematics Teachers' Difficulties with Contextual, Conceptual, and Procedural Knowledge. Scandinavian Journal of Educational Research, 63(1), 105-123. https://doi.org/10.1080/00313831.2017.1324906

Beilstein, S. O. (2019). Supporting Children's Conceptual Understanding of Fractions With Manipulative and Gesture. In $A \gamma \alpha \eta$ (Vol. 8, Issue 5).

Bergsten, C., Engelbrecht, J., \& Kågesten, O. (2017). Conceptual and procedural approaches to mathematics in the engineering curriculum - comparing views of junior and senior engineering students in two countries. Eurasia Journal of Mathematics, Science and Technology Education, 13(3), 533-553. https://doi.org/10.12973/eurasia.2017.00631a

Blume, F., Dresler, T., Gawrilow, C., Ehlis, A. C., Goellner, R., \& Moeller, K. (2021). Examining the relevance of basic numerical skills for mathematical achievement in secondary school using a

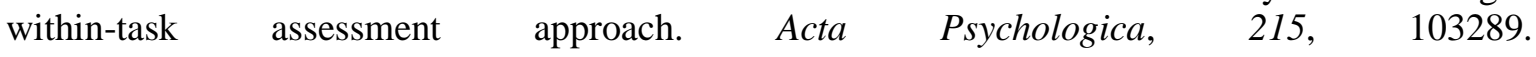
https://doi.org/10.1016/j.actpsy.2021.103289

Chang, Y. P., Krawitz, J., Schukajlow, S., \& Yang, K. L. (2020). Comparing German and Taiwanese secondary school students' knowledge in solving mathematical modelling tasks requiring their assumptions. ZDM - Mathematics Education, 52(1), 59-72. https://doi.org/10.1007/s11858-01901090-4

Daubert, E. N., \& Ramani, G. B. (2019). Math and Memory in Bilingual Preschoolers: The Relations Between Bilingualism, Working Memory, and Numerical Knowledge. Journal of Cognition and Development, 20(3), 314-333. https://doi.org/10.1080/15248372.2019.1565536

Engelbrecht, J., Bergsten, C., \& Kågesten, O. (2017). Conceptual and procedural approaches to mathematics in the engineering curriculum: views of qualified engineers*. European Journal of Engineering Education, 42(5), 570-586. https://doi.org/10.1080/03043797.2017.1343278

Herppich, S., \& Wittwer, J. (2018). Preservice teachers' beliefs about students' mathematical knowledge structure as a foundation for formative assessments. Teaching and Teacher Education, 76, 242-254. https://doi.org/10.1016/j.tate.2018.06.011

Hurrell, D. (2021). Conceptual Knowledge OR Procedural Knowledge or Conceptual Knowledge AND Procedural Knowledge: Why the Conjunction is Important to Teachers. Australian Journal of Teacher Education, 46(2), 57-71. https://doi.org/10.14221/ajte.2021v46n2.4

Kadijevich, D. M. (2018). Relating procedural and conceptual knowledge. Teaching of Mathematics, $21(1), 15-28$.

Lai, M. Y., Kinnear, V., \& Fung, C. I. (2019). Teaching Mathematics for Understanding in Primary Schools: Could Teaching for Mathematising Be a Solution?. International Journal for Mathematics Teaching and Learning, 20(1), 1-17.

Legesse, M., Luneta, K., \& Ejigu, T. (2020). Studies in Educational Evaluation Analyzing the e ff ects of mathematical discourse-based instruction on eleventh-grade students ' procedural and conceptual understanding of probability and statistics. Studies in Educational Evaluation, 67(July), 100918. https://doi.org/10.1016/j.stueduc.2020.100918

Lenz, K., Dreher, A., Holzäpfel, L., \& Wittmann, G. (2020). Are conceptual knowledge and procedural knowledge empirically separable? The case of fractions. British Journal of Educational Psychology, 90(3), 809-829. https://doi.org/10.1111/bjep.12333

Levin, M. (2018). Conceptual and Procedural Knowledge During Strategy Construction: A Complex 
DOI: https://doi.org/10.47405/mjssh.v6i12.1178

Knowledge Systems Perspective. Cognition and Instruction, 36(3), 247-278. https://doi.org/10.1080/07370008.2018.1464003

Ling, C. Y., Osman, S., Daud, M. F., \& Hussin, W. N. W. (2019). Application of vee diagram as a problem-solving strategy in developing students' conceptual and procedural knowledge. International Journal of Innovative Technology and Exploring Engineering, 8(10), 2796-2800. https://doi.org/10.35940/ijitee.J9591.0881019

Mairing, J. P. (2016). Thinking Process of Naive Problem Solvers to Solve Mathematical Problems. International Education Studies, 10(1), 1. https://doi.org/10.5539/ies.v10n1p1

Morales, N., Dartnell, P., \& Gómez, D. M. (2020). A Study on Congruency Effects and Numerical Distance in Fraction Comparison by Expert Undergraduate Students. Frontiers in Psychology, 11(June), 1-14. https://doi.org/10.3389/fpsyg.2020.01190

Namkung, J. M., \& Bricko, N. (2020). The Effects of Algebraic Equation Solving Intervention for Students With Mathematics Learning Difficulties. https://doi.org/10.1177/0022219420930814

Ocal, M. F. (2017). The Effect of Geogebra on Students' Conceptual and Procedural Knowledge: The Case of Applications of Derivative. Higher Education Studies, 7(2), 67. https://doi.org/10.5539/hes.v7n2p67

Otun, W. I., \& Olaoye, A. A. (2019). Enhancing the Conceptual, Procedural and Flexible Procedural Knowledge of Pre-Service Mathematics Teachers in Algebra. JRAMathEdu (Journal of Research and Advances in Mathematics Education), 4(2), 66-78. https://doi.org/10.23917/jramathedu.v4i2.8363

Radmehr, F., \& Drake, M. (2020). Exploring students' metacognitive knowledge: The case of integral calculus. Education Sciences, 10(3). https://doi.org/10.3390/educsci10030055

Rahman, A., \& Ahmar, A. S. (2016). Exploration of mathematics problem solving process based on the thinking level of students in junior high school. International Journal of Environmental and Science Education, 11(14), 7278-7285. https://doi.org/10.5281/zenodo.240664

Rittle-Johnson, B. (2017). Developing Mathematics Knowledge. Child Development Perspectives, 11(3), 184-190. https://doi.org/10.1111/cdep.12229

Rittle-Johnson, B., Fyfe, E. R., \& Loehr, A. M. (2016). Improving conceptual and procedural knowledge: The impact of instructional content within a mathematics lesson. British Journal of Educational Psychology, 86(4), 576-591. https://doi.org/10.1111/bjep.12124

Rittle-Johnson, B., \& Schneider, M. (2015). Developing Conceptual and Procedural Knowledge of Mathematics. Oxford Handbook of Numerical Cognition, 1, 1118-1134. http://oxfordhandbooks.com/view/10.1093/oxfordhb/9780199642342.001.0001/oxfordhb9780199642342-e-014

Rittle-Johnson, B., Schneider, M., \& Star, J. R. (2015). Not a One-Way Street: Bidirectional Relations Between Procedural and Conceptual Knowledge of Mathematics. Educational Psychology Review, 27(4), 587-597. https://doi.org/10.1007/s10648-015-9302-x

Saiman, Wahyuningsih, P., \& Hamdani. (2017). Conceptual or procedural mathematics for engineering students at University of Samudra. Journal of Physics: Conference Series, 855(1). https://doi.org/10.1088/1742-6596/855/1/012041

Satsangi, R., Hammer, R., \& Bouck, E. C. (2020). Using Video Modeling to Teach Geometry Word Problems: A Strategy for Students With Learning Disabilities. Remedial and Special Education, 41(5), 309-320. https://doi.org/10.1177/0741932518824974

Stoyle, K. L., \& Morris, B. J. (2017). Blogging mathematics: Using technology to support mathematical explanations for learning fractions. Computers and Education, 111, 114-127. https://doi.org/10.1016/j.compedu.2017.04.007

Sylviyani, H. (2017). Etnomatematika: Aplikasi bangun datar segiempat pada candi Muaro Jambi. $8(2), 99-110$.

Torres-Carrion, P. V., Soledad, C., Aciar, S., \& Rodriguez-Morales, G. (2018). Methodology for Systematic Literature Review applied to Engineering and Education. 1364-1373.

Vamvakoussi, X., Bempeni, M., Poulopoulou, S., \& Tsiplaki, I. (2019). Theoretical and methodological issues in the study of conceptual and procedural knowledge : Reflections on a series of studies on Greek secondary students' knowledge of fractions. 6(2), 82-96.

Watson, S. M. R., Lopes, J., Oliveira, C., \& Judge, S. (2018). Error patterns in Portuguese students' addition and subtraction calculation tasks: Implications for teaching. Journal for Multicultural Education, 12(1), 67-82. https://doi.org/10.1108/JME-01-2017-0002 
Wawan, Talib, A., \& Djam'an, N. (2019). Analisis Pemahaman Konseptual dan Prosedural Siswa dalam Menyelesaikan Soal Matematika Berdasarkan Gaya Belajar. Issues in Mathematics Education (IMED), 1(2), 101-106.

Yummiyati, K., Sujadi, I., \& Indriati, D. (2019). Cognitive Level Profile At the Tenth Grade of Senior High School Students in Mathematics Problem. Nternational Online Journal of Education and Teaching (IOJET), 6(3). http://iojet.org/index.php/IOJET/article/view/535, diakses Jumat 2 Juli 2021

Yurniwati. (2019). Improving the Conceptual and Procedural Knowledge of Prospective Teachers through Multisensory Approach: Experience from Indonesia. JRAMathEdu (Journal of Research and Advances in Mathematics Education), 3(2), 106-117. https://doi.org/10.23917/jramathedu.v3i2.6783

Zulnaidi, H., \& Zamri, S. N. A. S. (2017). The effectiveness of the geogebra software: The intermediary role of procedural knowledge on students' conceptual knowledge and their achievement in mathematics. Eurasia Journal of Mathematics, Science and Technology Education, 13(6), 21552180. https://doi.org/10.12973/eurasia.2017.01219a 